\title{
EFFECT OF GREEN MARKETING STRATEGY AND PRICES ON CONSUMER LOYALTY (STUDY OF STUDENT CASE ISLAMIC HIGH PROTECTIONIN THE MEDAN CITY)
}

\author{
Rini Astuti, S.E.,M.M ${ }^{1}$, Ikhsan Abdullah, SE., M.Si ${ }^{2}$ \\ University Of Muhammadiyah Sumatera Utara \\ riniastuti@umsu.ac.id ${ }^{1}$, ikhsanabdullah@umsu.ac.id ${ }^{2}$
}

\begin{abstract}
This study was conducted to determine the effect of green marketing strategy and price that can affect consumer loyalty. This study used quantitative descriptive research, and the population in this study were students of Muhammadiyah University of North Sumatra, Islamic University of North Sumatra and Muslim University Nusantara Al-Washliyah using Mustika Ratu beauty products. Because students who use beauty products in private Islamic colleges cannot be known or cannot be measured in number then the sampling is done by using Nonprobability sampling technique. Where as many as 140 respondents are sampled, data collection is done by spreading the questionnaire (quisioner) in analyzing data in this research that is using multiple linear regression formula, $t$ test, $f$ test, and coefficient of determination. The result of this research is a significant influence between green marketing strategy to purchase decision $0.000<0,05$, likewise between variable of price to consumer loyalty where there is significant influence. While the magnitude coefficient of determination R2 is equal to $76,9 \%$, the rest of $23.1 \%$ influenced by other factors.
\end{abstract}

Keywords: Green Marketing Strategy, Price, Consumer Loyalty

\section{INTRODUCTION}

The development of cosmetics beauty products provide business opportunities for cosmetics manufacturers. Competition that occurs in the cosmetics product business where each company continuously strives to produce high quality products so as to compete with existing products. Despite efforts to improve product quality, many of the beauty products companies are not responsible for using a mixture of harmful chemicals prohibited by BPOM so as to interfere with the health of cosmetic users.

Cosmetic products with high chemical content from large factories are considered not environmentally friendly. That's because the process of making pollute nature and is not safe to eat. From there a new variant of green cosmetic is a series of cosmetics and skin care that is safe for health and environmentally friendly.

Green Cosmetic is an eco-friendly cosmetics made from natural base material without chemicals and artificial coloring. Green Cosmetic also does not harm the environment because the process of using energy efficiency.

Green Cosmetic as a strategy undertaken by Mustika Ratu beauty products in winning the competition in the market amid issues of rampant cosmetics containing hazardous chemicals.

The development of cosmetics beauty products provide business opportunities for cosmetics manufacturers. Competition that occurs in the cosmetics product business where each company continuously strives to produce high quality products so as to compete with existing products. Despite efforts to improve product quality, many of the beauty products companies are not responsible for using a mixture of harmful chemicals prohibited by BPOM so as to interfere with the health of cosmetic users.

Cosmetic products with high chemical content from large factories are considered not environmentally friendly. That's because the process of making pollute nature and is not safe to eat. From there a new variant of green cosmetic is a series of cosmetics and skin care that is safe for health and environmentally friendly. 
Green Cosmetic is an eco-friendly cosmetics made from natural base material without chemicals and artificial coloring. Green Cosmetic also does not harm the environment because the process of using energy efficiency.

Green Cosmetic as a strategy undertaken by Mustika Ratu beauty products in winning the competition in the market amid issues of rampant cosmetics containing hazardous chemicals. Mustika Ratu products provide natural cosmetics based on plants, do not use chemicals that are harmful to the skin and environmentally friendly, Mustika Ratu's product design has its own distinctive characteristic as well as green cosmetic recyclable packaging, Mustika Ratu also displaying HALAL text on every packing of cosmetic products. In conducting the production process of Mustika Ratu's product has applied CPKB (Good Production Method Cosmetics), that is the green cosmetic strategy applied by Mustika Ratu.

The attractiveness of a product can not be removed from a price such as money, time, cognitive activity, behavioral effort, value and pricing. Prices will tend to explain the quality of the product. Now consumers tend to demand a price that matches the quality of the product, let alone the female consumer. They pay more attention to the elements of price and product quality. The ability of consumer knowledge is now growing. Consumers will continue to consider the greatest benefits they will receive that will then be willing to pay more for the convenience, appearance, reliability and prestige felt from the good quality of the product to buy. From everyday observations it can be seen that women dominate consumption of cosmetic products, although this does not mean that men do not consume them at all. Naturally, women want to always look beautiful and attractive in every opportunity. Cosmetics is a tool to realize the need for such beauty. In general, people usually define cosmetics as a tool or material used to beautify, beautify, even to nourish the body desired.

With the green cosmetic strategy and the applied price of Mustika Ratu, consumers will feel satisfaction based on the valuation as well as the benefits of using the product so that consumers make purchases and grow loyalty. Consumer loyalty is consumer loyalty to a product and repeat purchase.

Based on research results Aniza Octviani (2013) revealed that the green marketing or marketing strategy that uses environmental issues positively affect the customer's loyalty of the body shop among students this is because consumers feel the satisfaction and benefits with the green marketing strategy that fosters loyalty, thus hypothesis which is proven to be true.

In some Islamic Private universities Medan green cosmetic has not much to understand especially among teenage daughters due to the still low awareness of the students will be environmentally friendly cosmetics (Green Cosmetic) And still there are female students who prefer to use cosmetics made from the danger prohibited by BPOM compared to cosmetics already guaranteed security like Mustika Ratu cosmetic products.

\section{RESEARCH PURPOSES}

The purpose of this research is to know whether there is influence of green marketing strategy to consumer loyalty and to know influence of price to consumer loyalty partially. And to find out if there is influence of green marketing strategy and price simultaneously to consumer loyalty cosmetics Mustika Ratu.

\section{THEORETICAL BASIS}

\section{Strategy}

Strategy is the company's way to achieve goals or goals both short-term goals and long-term goals. Strategy in a business or business world is needed to achieve the vision and mission that has been applied by the company.

According to David (2011) Strategy is a joint means with long-term goals to be achieved. Business strategies include geophysical expansion, diversification, acquisition, product development, market penetration, tightening, divestiture, liquidation, and joint ventures. Strategies are potential actions that require top management decisions and large amounts of enterprise resources. So strategy is an action action or activity done by a person or company to achieve goals or goals.

According Rangkuti (2013) argues that the strategy is a comprehensive master planning, which explains how the company will achieve all the goals that have been set based on the mission that has been set previously. 
According to Pearce II and Robinson (2010) strategy is a large-scale plan, with a future orientation, in order to interact with the conditions of competition to achieve corporate goals. According to Mintzberg (2010), the concept of strategy includes at least five interrelated meanings or meanings, where the strategy is:

1. Planning to further clarify the direction of the organization in a rational way to realize its long-term goals.

2. References pertaining to the assessment of consistency or inconsistency of conduct and actions taken by the organization.

3. Angle positioned by the organization when it comes to its activity.

4. A perspective concerning an integrated vision between the organization and its environment that becomes the boundary for its activity.

5. Details of the organization's tactical steps containing information to trick competitors.

\section{Green Marketing}

Green marketing is a marketing that uses environmental issues on all aspects of marketing.

According to the American Marketing Association (AMA) in Hawkins and Mothershaugh (2010) defines green marketing is a process of marketing products that are assumed safe to the environment and safe to eat. Green marketing can be said to not only offer products that are only environmentally friendly, but also includes the production process, as well as product modification activities.

Lozada (2010) defines Green Marketing as "the application of marketing tools to facilitate change that provides organizational satisfaction and individual goals in the maintenance, protection and conservation of the physical environment".

According to Sumarwan et al. (2012) stating that green marketing is not merely to market environmentally friendly products, but demands a reorientation and environmental responsibility of the entire areas, activities, and departments of an organization.

According to Heino, (2012) Green Cosmetic can generally be interpreted as cosmetics made from natural raw materials and made with a process that does not destroy nature, All materials and processes have passed the standardization process based on applicable rules.

According to Sivertsen in Naomi (2011) Green cosmetics are cosmetics whose raw materials are developed in organic standards. Organic standards are the standard by which raw materials used to make products are not sprayed with pesticides and do not use other chemical fertilizers.

According to the Organization that regulates the eco-friendly cosmetics of Natural Product Associations (NPA) there are some rules about green cosmetics:

1. A product may attach $100 \%$ organic label if all ingredients have been tested organic or meet organic standards of the National Organic Strandarization Board. These materials may come from flora, fauna, minerals and their by-products.

2. A product can attach an organic label if $95 \%$ of the ingredients are tested and meet organic standards. The remaining $5 \%$ can use synthetic materials, if its existence does not endanger the health or safety of its users or if there is no alternative natural replacement.

3. A product can paste labels made of organic materials if more than $70 \%$ of the ingredients are tested and through organic standards.

\section{Benefits of Green Cosmetic}

According to Scientific Adviser Nu Skin Enterprises Dr. Paul Alan Cox The more benefits we can make when using green cosmetics, such as the product is more quickly absorbed by the body due to the nature of the ingredients are natural, and usually does not cause side effects such as allergic reactions. By using green cosmetics we can also reduce the chemicals used for the skin, and these eco-friendly products contain more antioxidants $\pm 40 \%$.

Paramita \& Yasa (2015) Benefits of Green Cosmetics (green cosmetic), namely:

1. No animal testing: In some cosmetic messages there is always an explicit message like this. The absence of animal experiments in the cosmetics manufacturing process has helped the cosmetics become eco-friendly cosmetics. In addition, the cosmetics do not rely on animals as experimental materials so that no harm. For that, it would be better to choose cosmetics with labels like this, then we save and preserve the fauna. Nor does it also torture animals. 
2. Natural ingredients: Usually green cosmetics will use natural ingredients as the main ingredient in cosmetics. Like from seeds, some plants and flowers as a cosmetic content. In addition to raw materials that are easy to find, this cosmetic is also certainly safe for your consumption and your skin. Because it comes from nature not from chemicals.

\section{Price}

According to Kotler and Keller (2009), price is one of the marketing mix elements that generate revenue, other elements generate costs. Price is the easiest element in a marketing program to customize product features, channels, and even communication takes a lot of time. According to Fandy Tjiptono (2008), mention price is the only marketing mix that provides income or income for the company.

Meanwhile, according to Kotler and Amstrong (2008), the price is the sum of money that is levied on a product or service or the sum of the value exchanged by customers to benefit from owning or using a product or service. From the above definition can be explained that the price is a sum of money value including goods and services offered to replace the property rights of a good and service to another party.

\section{Consumer Loyalty}

Consumer loyalty in general can be interpreted as a person's loyalty to a product, both goods and services. When consumers or customers have been loyal then it is not easy to be interested in persuasion competitors.

According to Hurriyati (2010), "Consumer loyalty is a deeply enduring commitment of consumers to re-subscribe or re-purchase consistent products / services consistently in the future, although the influence of the marketing situation and efforts has the potential to cause behavioral change."

According to Kotler and Keller (2009), consumer loyalty is a deeply held commitment to buy or support preferred products or services in the future even if the influence of the marketing situation and effort has the potential to drive customers.

According to Hasan (2011) that consumer loyalty is a consumer who simply does not repurchase any goods and services for example by recommending others to buy.

\section{Factors Affecting Consumer Loyalty}

According to Robinette (2010) the factors that influence consumer loyalty are caring, trust, protection (length of patronage), and cumulative satisfaction (overall satisfaction).

1. Caring, the company must be able to see and overcome all the needs, hopes, and problems faced by consumers. With that attention, consumers will be satisfied with the company and re-transact with the company, and eventually they will become loyal corporate customers. The more companies show their attention, the greater the consumer loyalty will arise.

2. Namely trust (belief), trust arises from a long process until both parties sating trust. If trust is established between the consumer and the company, the effort to develop it will be easier, the company and consumer relationships are reflected in the trust level of the customers. If the level of customer confidence is high, then the firm's relationship with the consumer will be strong. One way that companies can do in developing relationships with consumers, ie all types of products produced by the company must have the quality or perfection as it should or as promised, so that consumers do not feel cheated, which can lead consumers to move to competitor products.

3. Protection (length of patronage), the company must be able to provide protection to consumers, whether in the form of product quality, service, complaint or after-sales service. Thus, consumers do not worry the company in doing transactions and associated with the company.

4. Accumulative satisfaction (overall satisfaction), accumulative satisfaction is the overall valuation based on the total purchase and consumption of goods and services at a certain period .. Therefore, the company should be able to provide a sense of satisfaction to consumers, should pay attention and improve the function and usefulness of all facilities and resources owned so that consumers can use it anytime and anywhere. 
According to Zikmund in Vanessa (2009), consumer loyalty is influenced by five factors, namely:

1. Satisfaction (satisfaction)

Consumer satisfaction is a comparison between expectations before making a purchase with perceived performance.

2. Emotional bonding (emotional bond)

Consumers can be affected by a brand that has its own charm so that consumers can be identified in a brand, because a brand can reflect the characteristics of the consumer. The bond that is created from a brand is when the consumer feels a strong bond with other customers who use the same product or service.

3. Trust (trust)

The willingness of a person to entrust a company or a brand to perform or execute a function.

4. Choice reduction and habbit (ease)

If consumers will feel comfortable with a brand when the situation they make the transaction provides convenience. Part of customer loyalty such as purchasing products on a regular basis can be based on accumulated experience at any time.

5. History with company

A person's experience in a company can shape behavior. When we get good service from the company, then we will repeat our behavior on the company.

\section{Benefits of Consumer Loyalty}

Griffin (2010) suggests benefits to be gained when companies have loyal customers include:

1. Can reduce marketing costs because the cost to attract new customers more expensive.

2. Can reduce transaction costs, such as negotiation fees, contracts, and order processing.

3. Can reduce the cost of turn over consumers due to less consumer replacement.

4. Can increase cross selling, which will increase the market share of the company, where loyal consumers will try and use other products offered by the company, thus enlarging the market share of the company.

5. Encourage a more positive word of mouth, assuming that loyal customers also mean those who are satisfied.

6. Can reduce the cost of failure in the sense of costs incurred to get a new consumer does not produce anything or prospective customers targeted failed to get.

\section{RESEARCH HYPOTHESIS}

Hypothesis is a suspected or temporary answer to the problem to be verified, through analysis of relevant data and the truth will be known after the research. The hypothesis of this research are:

H1: Green cosmetic strategy influences consumer loyalty in Private Islamic University of Medan City

H2: Price affects consumer loyalty in Islamic Higher Education of Medan City

H3: Green cosmetic and price strategy influential on consumer loyalty in Islamic Higher Education of Medan City

\section{HYPOTHESIS TESTING}

To see the effect of independent variables simultaneously on the dependent variable using Test $\mathrm{F}$. Meanwhile, to see the effect of green cosmetic variables and price variables partially on consumer loyalty using $t$ test.

\section{METEDOLOGY RESEARCH}

The success of a study depends heavily on the methodology used, because the methodology is basically the way used to answer the research question. Therefore, the selection of methodology needs to be done carefully and carefully.

In this study the authors use the approach of associative data. The approach according to Sugiyono (2012) "is a research that is asking the relationship between two or more variables". This study aims to determine whether there is a relationship or influence between two variables. 


\section{RESEARCH RESULTS AND DISCUSSION}

\section{Classic assumption test}

Classical assumption test is done for all variables before doing multiple linear regression test

\section{a. Normality test}

The purpose of the normality test, of course, to determine whether a variable is normal or not. Normal here in the sense of having a normal data distribution. Normal or not the data based on the standard distribution of data with the same mean and standard deviation. So the normality test basically performs a comparison between the data we have with the normal distribution having the mean and standard deviation equal to the data.

To find out whether this research data has normal or can not see from normality test through SPSS whether to form normal data or not.

\section{b. Multicollinearity Test}

According Ghozali (2005), "multicollinearity test aims to test whether the regression model found the existence of correlation between independent variables (independent)". In a good regression model there should be no correlation between independent variables, due to the high correlation between the independent variables in a multiple linear regression model. If there is a high correlation between the independent variables, then the relationship between independent variables to the dependent variable to be disturbed Multicollinearity testing is done by looking at the VIF between independent variables. If VIF indicates a number smaller than 10 indicating there are no symptoms of multicolinearity. In addition, a model is said to have multicolinearity symptoms if the VIF value among independent variables is greater than 10 .

\section{c. Heterocedasticity Test}

According to Ghozali (2005: 105) "heteroscedasticity test aims to test whether in the regression model there is a variance inequality of residual one observation to another observation, because to see whether there is an inequality of variance from one residual to observation to another. A regression model that meets the requirements is where there is a similarity of variance from the residual one observation to another fixed observation or called homoscedasticity. A good regression model is no heteroscedasticity. There are several ways to test whether there is a heteroscedasticity situation in the variant error terms for the regression model. In this research will be used chart method (Scatterplot Diagram), with the rationale that:

1) If there are certain patterns such as points (points), which exists form a certain pattern that regular (wavy, widened, then narrowed), then heteroscedasticity occurs.

2) If there is a clear pattern, and the spots spread upward and below 0 on the $\mathrm{Y}$ axis then no heteroscedasticity occurs.

\section{Hypothesis testing}

Test $\mathbf{t}$

$\mathrm{T}$ test is done for how much influence of profitability and environmental performance partially to company value. Statistical Test Result $\mathrm{t}$ shows the influence of green cosmetic strategy, price to consumer loyalty as follows:

1. The first hypothesis is the green cosmetic strategy has a significant effect on consumer loyalty. The result of $t$ test shows $t$ value of $t_{\text {hitung }} 7,342>1,657 t_{\text {table }}$ with significant level 0.000 . This means that green cosmetics have a significant effect on consumer loyalty. This means the first hypothesis (H1) is accepted.

2. The second hypothesis is that prices have a significant effect on consumer loyalty. The result of $t$ test shows $t$ value $t_{\text {hitung }} 8,276>t_{\text {table }} 1,657$ with significant level 0.000 . This means that prices have a significant effect on consumer loyalty. This means that the second hypothesis (H2) is accepted. 


\section{Test F}

$\mathrm{F}$ test is done to see the effect of independent variable to dependent variable simultaneously. $\mathrm{F}$ test results obtained Fcount $F_{\text {hitung }} 195.003>F_{\text {table }} 3.07$ with a significant level of 0.000 then the decision is green cosmetic strategy and price significantly influence consumer loyalty.

\section{Coefficient of Determination}

From the results of determination test can be seen that 0.769 and this states that the variable influence of green cosmetic strategy and price of $76.9 \%$ to influence the consumer loyalty variable the rest influenced by other factors or other variables.

\section{The Influence of Green Marketing Strategy To Consumer Loyalty}

Green marketing is not just marketing environmentally friendly products, but demands a reorientation and environmental responsibility of the entire area, activities, and departments of an organization. Rudi Haryadi (2013) concluded that the Green Marketing Strategy has a positive effect on consumer choice through Marketing Mix approach. It was also supported by Aniza Octiviani (2013) study which stated that green marketing strategy have positive effect to customer's loyalty among students.

\section{Price Influence On Consumer Loyalty}

Price is everything that consumers give to get the benefits offered by the company's marketing mix (Cannon, et al, 2008). In this case the price is a variable that can be controlled and determine the acceptance or absence of a product by the consumer. Price is one of the most important attributes that consumers evaluate. Companies need to monitor the prices set by their competitors so that the price determined by the company is not too high or vice versa, so the price offered can give consumers a desire to be loyal to the product.

Consumers who are aware of the price of the product will know the quality of the goods they receive in accordance with the amount of money sacrificed. However, not infrequently consumers demand a cheaper alternative to the conditions of the same product. Further research results Indah Dwi Kurniasih (2012) states that there is influence price on customer loyalty in Ahass 0002 Astra Motor Workshop Siliwangi Semarang.

\section{CONCLUSION}

The results of this test show the influence of green marketing strategy has a significant and positive impact on consumer loyalty, as well as prices have a significant and positive impact on consumer loyalty and test results simultaneously also obtained the results there is influence between green marketing and price to consumer loyalty.

\section{REFERENCES}

Aniza Octoviani. 2013. The Effect Of Green Marketing Strategy On Customer Loyalty The Body Shop Amongst Students.

David, Fred, R. 2011. Strategic Management. Issue 12, Salemba 4 Jakarta

Griffin. J. Customer Royalty (Growing And Maintaining Customer Loyalty). Jakarta: PT. Erland.

Hawkins, Mothersbaugh, D.I. 2010. Consumer Behavior: Building Marketing Strategy. 11th Edition. Mcgraw-Hill, Irwin.

Heino, A. 2012. Natural Cosmetics As An Innovation, 22-28, Turku University Of Applied Sciences, Turku.

Hurriyati, Ratih. 2010. Marketing Mix And Consumer Loyalty, Alfabeta, Bandung.

Kotler, Philip and Gary Armstrong. 2014. Principles of Marketing Issue 12 Volume 1. PT Majana Cahaya Cemerlang

Lozada, H.R. 2010. Ecological Sustainability And Marketing Strategy. Review And Implication. Seton Hall University.

Mintzberg, Henry. 2010. Tracking Strategies: Toward A General Theory, Oxford University Press Inc. New York. 
Naomi, N. 2011. Behavioral Consumption Behavior Analysis Of Youth Products: Aida Model App (Attention, Interest, Desire, And Action). Thesis Department Of Family And Consumer Science Faculty Of Human Ecology Bogor Agricultural University.

Hatching, Freedy. 2013. Dissecting Business Case Business SWOT Analysis. Jakarta: PT Gramedia Pustaka Utama.

Robinette Scott \& Claire Brand. 2010. Emotion Marketing: Thr Hall Mark Way Of Winning Custome's For Life. New York. Mcgraw-Hill International.

Sumarwan, Ujang et al. 2012. Marketing And Consumer Research, Series 2. Bogor: PT Penerbit IPB Prees

Sugiyono. 2011. Understand Quantitative And Qualitative Research. Bandung: Alfabeta. 